\title{
Influence of Nano-Hydroxyapatite on the Metal Bioavailability, Plant Metal Accumulation and Root Exudates of Ryegrass for Phytoremediation in Lead-Polluted Soil
}

\author{
Ling Ding ${ }^{1}$, Jianbing $\mathrm{Li}^{2}$, Wei Liu ${ }^{1}$, Qingqing Zuo ${ }^{1}$ and Shu-xuan Liang ${ }^{1, *}$ \\ 1 College of Chemistry and Environmental Science, Hebei University, Key Laboratory of Analytical Science \\ and Technology of Hebei Province, Baoding 071002, China; 18730271511@163.com (L.D.); \\ auhlw80@126.com (W.L.); sunqc710@163.com (Q.Z.) \\ 2 Environmental Engineering Program, University of Northern British Columbia, Prince George, \\ BC V2N4Z9, Canada; Jianbing.Li@unbc.ca \\ * Correspondence: liangsx168@126.com; Tel.: +86-312-507-9749; Fax: +86-312-507-9739
}

Academic Editor: Susanne Charlesworth

Received: 11 December 2016; Accepted: 25 April 2017; Published: 16 May 2017

\begin{abstract}
Lead is recognized as one of the most widespread toxic metal contaminants and pervasive environmental health concerns in the environment. In this paper, the effects of nano-hydroxyapatite (NHAP) on remediation in artificially $\mathrm{Pb}$-contaminated soils and ryegrass were studied in a pot experiment. The addition of NHAP decreased the water- and acid-soluble, exchangeable, and reducible fractions of $\mathrm{Pb}$, extracted using the Community Bureau of Reference (BCR) method, whilst greatly increasing the residual fraction of $\mathrm{Pb}$. Oxidizable $\mathrm{Pb}$ was increased slightly. No significant increase in soil $\mathrm{pH}$ was caused by the application of NHAP. Compared to conditions without NHAP, the addition of NHAP decreased the Pb content in ryegrass shoots and roots by $13.19-20.3 \%$ and $2.86-21.1 \%$, respectively. Therefore, the application of NHAP reduced the mobility and bioavailability of $\mathrm{Pb}$ in the soil. In addition, the application of NHAP improved the fresh weight of shoots and roots, and promoted the growth of ryegrass. NHAP played a positive role in stimulating ryegrass to secrete tartaric acid.
\end{abstract}

Keywords: nano-hydroxyapatite; ryegrass; $\mathrm{Pb}$-polluted soil

\section{Introduction}

Soil pollution by heavy metals has become a serious concern in many developing countries due to intense industrialization and urbanization. Heavy metals are more complex than other environmental pollutants because they can be toxic to all living organisms. They are not biodegradable and tend to accumulate in tissues [1]. Lead is recognized as one of the most widespread toxic metal contaminants and pervasive health concerns in the environment [2]. It is generated from the natural weathering of rocks and industrial activities, including mining and lead ore smelting, lead-acid battery manufacturing, lead-based paints, etc. [3]. In addition, $\mathrm{Pb}$ is not an essential nutrient in the metabolic processes of plants and animals, and it can accumulate to high levels and have biological toxicity to organisms [4,5]. The limit for $\mathrm{Pb}$ content is $35 \mathrm{mg} / \mathrm{kg}$, according to the environmental quality standards for soils [6]. Therefore, the development of remediation strategies for Pb-contaminated soils is very important for human health and ecological protection.

Currently, most researchers focus on the use of chemical remediation and phytoremediation to control soil heavy metal pollution $[7,8]$. There have been a number of studies on in situ immobilization of $\mathrm{Pb}$-contaminated soils using hydroxyapatite, and two different mechanisms were 
mainly found: Dissolution-precipitation and ion exchange (between $\mathrm{Pb}^{2+}$ in solution and $\mathrm{Ca}^{2+}$ on hydroxyapatite lattice) [9]. The influence of both is dependent on $\mathrm{pH}$ and pore solution chemistry [10]. In general, hydroxyapatite has a better effect in acidic soil ( $\mathrm{pH} \sim 5)$, but the soil in our experiment was alkaline soil ( $\mathrm{pH} \sim 8$ ). Therefore, hydroxyapatite did not apply in our experiment. Nanomaterials have a higher reactivity and adsorption capacity than ordinary-sized materials. Nano-hydroxyapatite (NHAP) is an important mineral component of human hard tissues, such as bones and teeth, and is the less soluble form of phosphate. It is an ideal material for the immobilization of heavy metals because of its high sorption capacity for heavy metals, low water solubility, high stability under reducing and oxidizing conditions, availability, and cost effectiveness [11]. At present, the application of nano-hydroxyapatite on $\mathrm{Pb}$-contaminated soils is limited. The purpose of this study was to evaluate the effectiveness of nano-hydroxyapatite in immobilizing $\mathrm{Pb}$ in contaminated soils. Compared with most hyperaccumulators, ryegrass is preferentially used for phytoremediation because it is extensively grown, easy to be managed, and has a high biomass, therefore, it is economical to use it for phytoremediation [12]. Ryegrass can accumulate a large amount of toxic substances, and has a high tolerance to heavy metals [13]. Thus, for this experiment we selected ryegrass as a phytoremediation plant.

Our previous work studied the effect of $0.5 \%(w / w)$ NHAP on Pb-polluted soil, and the results showed that NHAP reduced the $\mathrm{Pb}$ contents of ryegrass [14]. However, at present, there are few studies on the immobilization of $\mathrm{Pb}$ using NHAP; especially, there is no research about the combination of NHAP and ryegrass, and the reasons for the reduced mobility and bioavailability of $\mathrm{Pb}$ caused by NHAP have not been fully investigated. In this paper, we studied the effects of higher NHAP applications at different $\mathrm{Pb}$ contents in the remediation of $\mathrm{Pb}$-contaminated soil. The aim of this study was to investigate the effects of NHAP on the changes in the form of $\mathrm{Pb}$ in soil, and the accumulation $\mathrm{of} \mathrm{Pb}$ in ryegrass and the growth of ryegrass.

\section{Materials and Methods}

\subsection{Design of the Pot Experiment}

The tested soil $(0-20 \mathrm{~cm})$ was farm field soil extracted from Baoding City, Hebei Province, China. The soil was air-dried, crumbled and then milled $(2 \mathrm{~mm})$. The soil had a $\mathrm{pH}$ of $7.87,23.28 \mathrm{~g} / \mathrm{kg}$ organic matter, $8.43 \mathrm{~g} / \mathrm{kg}$ total nitrogen (TN), $7.62 \mathrm{~g} / \mathrm{kg}$ total phosphorus (TP), and a cation exchange capacity (CEC) of $1.40 \mathrm{~mol} / \mathrm{kg}$. The $\mathrm{pH}$ was measured on a $2: 5(w / v)$ water suspension of the soil sample after stirring for $10 \mathrm{~min}$ [15]. TN in the soil was determined using the Kjeldahl method [16]. The organic matter in the soil was determined using the potassium dichromate volumetric method. Total phosphorus was determined using the molybdate-ascorbic acid procedure at $700 \mathrm{~nm}$ [17]. Cation exchange capacity was determined using the compulsive exchange method with $1 \mathrm{~mol} / \mathrm{L}$ of ammonium acetate ( $\mathrm{pH} 7$ ) [18]. The background value of $\mathrm{Pb}$ in the soil was $58.28 \mathrm{mg} / \mathrm{kg}$. $\mathrm{Pb}$ was applied to the soil as $\mathrm{Pb}\left(\mathrm{NO}_{3}\right)_{2}$ at four concentrations $(0,400,800$, and $1200 \mathrm{mg} / \mathrm{kg}$ of dried soil). Lead-spiked soil was aged in a greenhouse for one month. Nano-hydroxyapatite was purchased from the Nanjing Emperor Nano Material Company (Nanjing, China) and had a purity greater than $96 \%$. The $\mathrm{pH}$ of NHAP was 8.11 , and the specific surface area was $154 \mathrm{~m}^{2} / \mathrm{g}$. The $\mathrm{pH}$ was measured on a 1:20 $(w / v)$ water suspension of the nano-hydroxyapatite samples after stirring for $1 \mathrm{~h} \mathrm{[19].}$ The Brunauer-Emmett-Teller (BET) surface area of the NHAP was determined by $\mathrm{N}_{2}$ sorption analysis at $77 \mathrm{~K}$ in a surface analyzer after degassing.

The pot experiments were conducted in a greenhouse with an air temperature of $22-25{ }^{\circ} \mathrm{C}$ at Hebei University. The design of the pot experiments for the different treatments is listed in Table 1. Twenty seeds of ryegrass were sown per pot, which was filled with $0.15 \mathrm{~kg}$ soil ( $60 \%$ moisture content) and $1.5 \mathrm{~g}$ NHAP. Pots without NHAP were used as a control. Three replicates were set for each treatment. Thirty days after germination, the samples of ryegrass were harvested by cutting the shoots at the soil surface, and the roots were carefully separated from the soil. Plants were thoroughly washed 
with running water, followed by distilled water, and then dried at $105^{\circ} \mathrm{C}$ for $1 \mathrm{~h}$, and then at $65^{\circ} \mathrm{C}$ in an oven (BGZ-30, Shanghai Boxun Industry and Commerce Company, Shanghai, China) until completely dry. They were finally weighed, and the dry weight of the plants was recorded [20]. The soil was air-dried, crumbled and then milled ( $2 \mathrm{~mm}$ ).

Table 1. Design of the pot experiments for the different treatments.

\begin{tabular}{ccc}
\hline Treatment & Pb-Spiked Content $\mathbf{( m g} / \mathbf{k g})$ & Addition Amount of NHAP $(\mathbf{g})$ \\
\hline $0 \mathrm{mg} / \mathrm{kg}$ & 0 & 0 \\
$0 \mathrm{mg} / \mathrm{kg}+\mathrm{NHAP}$ & 0 & 1.5 \\
$400 \mathrm{mg} / \mathrm{kg}$ & 400 & 0 \\
$400 \mathrm{mg} / \mathrm{kg}+\mathrm{NHAP}$ & 400 & 1.5 \\
$800 \mathrm{mg} / \mathrm{kg}$ & 800 & 0 \\
$800 \mathrm{mg} / \mathrm{kg}+\mathrm{NHAP}$ & 800 & 1.5 \\
$1200 \mathrm{mg} / \mathrm{kg}$ & 1200 & 0 \\
$1200 \mathrm{mg} / \mathrm{kg}+\mathrm{NHAP}$ & 1200 & 1.5 \\
\hline
\end{tabular}

NHAP: nano-hydroxyapatite.

\subsection{Pb Content Determination}

Shoot or root dry matter $(0.1 \mathrm{~g})$ was digested using $5 \mathrm{~mL} \mathrm{HNO}_{3}$ and $2 \mathrm{~mL} \mathrm{H}_{2} \mathrm{O}_{2}$. Soil samples ( $0.1 \mathrm{~g}$ ) were digested with $5 \mathrm{~mL} \mathrm{HNO}_{3}, 2 \mathrm{~mL} \mathrm{H}_{2} \mathrm{O}_{2}$ and $2 \mathrm{~mL} \mathrm{HF}$. The Pb concentration in the digested solutions was determined using an $\mathrm{A} 3$ atomic absorption spectrophotometer (Beijing Purkinje General Instrument Co., Ltd., Beijing, China). The standard reference material (GBW 07411, National Institute of Metrology, Beijing, China) was analyzed with the samples during the course of the analyses. The linear correlation coefficient of the $\mathrm{Pb}$ standard solution was $r>0.999$. The mean recovery of the $\mathrm{Pb}$ standard reference material was $98 \%$. The range of the $\mathrm{Pb}$ standard solution was $1-15 \mathrm{mg} / \mathrm{L}$.

\subsection{Determination of $\mathrm{pH}$}

Four grams of soil sample were put into plastic centrifuge tubes. Then, $10 \mathrm{~mL}$ of distilled water was added to the tubes. The mixture of soil and solution was stirred for $10 \mathrm{~min}$ and then allowed to settle for $30 \mathrm{~min}$. The $\mathrm{pH}$ value was measured using a $\mathrm{pH}$ meter (HACH, Loveland, $\mathrm{CO}, \mathrm{USA})$.

\subsection{Organic Acids Analysis}

A portion of the ryegrass rhizosphere soil was collected during the collection of the plant samples and kept at $4{ }^{\circ} \mathrm{C}$ for analysis. For organic acid extraction, $1.0 \mathrm{~g}$ of soil was extracted by $10 \mathrm{~min}$ of agitation at $200 \mathrm{rpm}$ with $10 \mathrm{~mL} 0.1 \mathrm{~mol} / \mathrm{L} \mathrm{H}_{3} \mathrm{PO}_{4}$, and the extracts were filtered using a $0.2 \mathrm{~mm}$ filter membrane. The separation of organic acids was carried out on a system consisting of an analytical high-performance liquid chromatography (HPLC) unit (Waters 1525 Binary HPLC Pump, Waters 2998 Photodiode Array Detector, Waters, Milford, MA, USA) with a Cosmosil packed column (C18-PAQ, $4.6 \mathrm{~mm}$ I. D., Nacalai Tesque, Kyoto, Japan), in conjunction with a column heating device set at $30^{\circ} \mathrm{C}$. Elution was carried out isocratically at a solvent flow rate of $1.0 \mathrm{~mL} / \mathrm{min}$ of $0.02 \mathrm{~mol} / \mathrm{L} \mathrm{NaH}_{2} \mathrm{PO}_{4}$ and chromatographic-grade acetonitrile (98:2). The injection volume was $20 \mu \mathrm{L}$. Detection was performed with a UV detector set at $213 \mathrm{~nm}$. The standard solution was prepared by mixing eight low molecular weight organic acids: tartaric acid, lactic acid, acetic acid, citric acid, pyruvic acid, oxalic acid, succinic acid, and L-malic acid. Organic acid identification was performed by comparison of the retention times with those of authentic standards. The peaks in the chromatograms were integrated using a default baseline construction technique. The organic acid was quantified by the peak area. 


\subsection{Community Bureau of Reference Sequential Extraction Tests}

The Community Bureau of Reference (BCR) was used to extract different fractions of $\mathrm{Pb}$ [21]. One gram of dried specimen of soil sample was added to a polypropylene centrifuge tube; the sequential extraction procedures are listed in Table 2.

Table 2. Sequential extraction procedure for soil $\mathrm{Pb}$.

\begin{tabular}{ccc}
\hline Fraction & Reagent & Shaking Time and Temperature \\
\hline Exchangeable (F1) & $40 \mathrm{~mL}$ of $0.11 \mathrm{~mol} / \mathrm{L} \mathrm{CH}_{3} \mathrm{COOH}$ & $16 \mathrm{~h}$ at $25^{\circ} \mathrm{C}$ \\
\hline $\begin{array}{c}\text { Reducible } \\
\text { (iron/manganese oxyhydroxides) (F2) }\end{array}$ & $40 \mathrm{~mL}$ of $0.5 \mathrm{~mol} / \mathrm{L} \mathrm{NH} \mathrm{HH}_{2} \mathrm{HCl}$ & $16 \mathrm{~h}$ at $25^{\circ} \mathrm{C}$ \\
\hline $\begin{array}{c}\text { Oxidizable } \\
\text { (organic matter and sulfides) (F3) }\end{array}$ & $\begin{array}{c}10 \mathrm{~mL} \mathrm{of} 8.8 \mathrm{~mol} / \mathrm{L} \mathrm{H} \mathrm{O}_{2}, \text { twice, } \\
\text { cool and add } 50 \mathrm{~mL} \mathrm{of} 1 \mathrm{~mol} / \mathrm{L} \mathrm{NH}{ }_{4} \mathrm{Ac}\end{array}$ & $\begin{array}{c}1 \mathrm{~h} \mathrm{~h} \text { at } 25^{\circ} \mathrm{C}, 1 \mathrm{~h} \text { at } 85^{\circ} \mathrm{C}, \\
1 \text { at } 85{ }^{\circ} \mathrm{C}, 16 \mathrm{~h} \text { at } 25^{\circ} \mathrm{C}\end{array}$ \\
\hline Residual (R) & $\mathrm{HNO}_{3}-\mathrm{H}_{2} \mathrm{O}_{2}-\mathrm{HF}$ & Microwave digestion \\
\hline
\end{tabular}

\subsection{Statistical Analysis}

All values are the means of three replicates. Data are presented as the mean value \pm standard deviation. To verify the statistical significance of differences among the treatments, data were analyzed using SPSS statistical software (IBM Nederland BV, Amsterdam, The Netherlands) using one-way ANOVA and Duncan's multiple-range test. Differences were considered significant at $p<0.05$.

\section{Results and Discussion}

\subsection{Speciation Analysis of $\mathrm{Pb}$ in Soil}

The use of sequential extraction furnished detailed information regarding the origin, mode of occurrence, biological and physicochemical availability, mobilization, and transport of heavy metals [22]. In this paper, BCR was used to evaluate the effect of NHAP on the changes of $\mathrm{Pb}$ fractions in the soil. It has been reported that conventional hydroxyapatite can react with $\mathrm{Pb}$ to form chloropyromorphite during the sequential extraction process (especially in the non-steady amended state) [23]. However, at present, the sequential extraction method is still a universally-applied method for the determination of heavy metal fractions. We attempted to avoid this possible error in the experiments by strictly controlling the experimental conditions, and placing the results of the BCR measurements in uniform and comparable conditions. According to the degree of heavy metal bioavailablity in different metal fractions, metal species were divided into three categories: bioavailable, potentially bioavailable, and bio-unavailable. The bioavailable category included the water soluble and exchangeable fractions. The content of this heavy metal portion was small, but had excellent mobility, and was most likely to be absorbed and utilized by organisms [24]. The mobility of heavy metals was directly related to water solubility, and the high water solubility of heavy metals can result in a high leaching risk for groundwater and can threaten the health of organisms [25].

As shown in Figure 1, the amounts of Pb present in F1 and F2 were noticeably lower after NHAP was added compared with the control group, declining by $21.69-66.08 \%$ and $25-52.02 \%$, respectively. The residual fraction of $\mathrm{Pb}$ increased by $124.67 \%$ compared with the control group. After adding $\mathrm{NHAP}$, the Pb content of F3 increased by $6.83 \%$ on average. Any changes for F3 were not as obvious as those of the other three $\mathrm{Pb}$ fractions. The results showed that the application of NHAP can change the fraction of $\mathrm{Pb}$ from bioavailable to bio-unavailable. NHAP significantly reduced the mobility and availability of $\mathrm{Pb}$ in soil. The portions of the four $\mathrm{Pb}$ fractions extracted using $\mathrm{BCR}$ were almost the same as soil with different applied $\mathrm{Pb}$ levels. The formation of pyromorphite from $\mathrm{Pb}$ was the most important effect of NHAP application [26]. This led the transformation of $\mathrm{Pb}$ from non-residual to residual fractions by changing its dissolution-precipitation mechanism. NHAP was first dissolved in soil solution which released phosphate ions, and then phosphate ions and lead ions in the soil solution 
produced a low solubility type of lead phosphate. Nanoparticles have a very large micro-interface, with a strong surface complexation ability with respect to heavy metals, which accelerates the rate of dissolution, shortening the equilibrium time between dissolution and sedimentation. The acidity required by dissolved nanoparticles was lower than larger particles, which can reduce the probability of acidification as secondary pollution in the processes of hydroxyapatite to immobile $\mathrm{Pb}$. Therefore, nano-scale materials are expected to improve the remediation effect. It was reported that the bioavailability of heavy metals in soil are linearly related to their biotoxicities [27]. The results showed that the application of NHAP could alleviate the biotoxicity of $\mathrm{Pb}$ and lower its mobility in soil to ensure the healthy growth and development of plants.

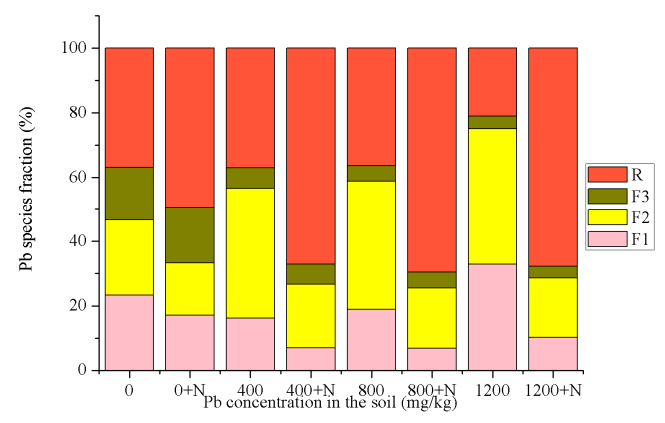

Figure 1. Lead partitioning in Pb-spiked soil with and without NHAP application. The values of $0,400,800,1200$ respectively stand for the addition of $\mathrm{Pb}$ content $(0,400,800,1200 \mathrm{mg} / \mathrm{kg})$; $0+\mathrm{N}, 400+\mathrm{N}, 800+\mathrm{N}, 1200+\mathrm{N}$ respectively stand for the addition of Pb content $(0,400,800$, $1200 \mathrm{mg} / \mathrm{kg}$ ) and NHAP (1.5 g). The operationally defined soil fractions were: (F1) exchangeable, (F2) reducible (iron/manganese oxyhydroxides), (F3) oxidizable (organic matter and sulfides), and (R) residual. N: nano-hydroxyapatite.

\subsection{Effect of Nano-Hydroxyapatite on the $\mathrm{pH}$ of Soil}

The $\mathrm{pH}$ of soil is an important parameter that affects metal immobilization and dissolution in soil. Metal solubility and mobility decreased with the increase in $\mathrm{pH}$. According to Table 3, the addition of NHAP increased soil $\mathrm{pH}$ by $0.02-0.13$ units, compared with the control group. However, this difference was not significant. The result was consistent with the finding that the application of NHAP can increase the soil $\mathrm{pH}$ value [3]. NHAP was dissolved in the soil solution, releasing $\mathrm{PO}_{4}{ }^{3-}$, and $\mathrm{PO}_{4}{ }^{3-}$ to react with the $\mathrm{H}^{+}$in the soil-generated $\mathrm{HPO}_{4}{ }^{2-}$ and $\mathrm{H}_{2} \mathrm{PO}_{4}{ }^{-}$[28]. Soil $\mathrm{pH}$ decreased with the rise of $\mathrm{Pb}$ content in soil, but there were almost no significant differences. For the $1200 \mathrm{mg} / \mathrm{kg}$ treatment, the $\mathrm{pH}$ of the soil had a larger reduction. In addition, the roots of plants can also affect soil $\mathrm{pH}$ by secreting protons and organic acids. The contents of heavy metals in soil have impacts on the secretion of plant roots [29]. Therefore, the observed tendency in this study might be the result of factors such as plant secretions, NHAP, and $\mathrm{Pb}$ content. More in-depth research to determine the specific impact of each factor on the $\mathrm{pH}$ of soil is needed.

Table 3. Effects of NHAP on rhizosphere soil pH. The different letters in the table represent significant differences between treatments at $p<0.05$.

\begin{tabular}{ccc}
\hline \multirow{2}{*}{$\begin{array}{c}\text { Exogenous Pb Concentration } \\
(\mathbf{m g} / \mathbf{k g})\end{array}$} & \multicolumn{2}{c}{ The Rhizosphere Soil $\mathbf{p H}$} \\
\cline { 2 - 3 } & Without NHAP & With NHAP \\
\hline 0 & $8.64 \pm 0.10^{\mathrm{a}, \mathrm{b}}$ & $8.66 \pm 0.03^{\mathrm{a}}$ \\
800 & $8.69 \pm 0.04^{\mathrm{a}}$ & $8.73 \pm 0.02^{\mathrm{a}}$ \\
1200 & $8.51 \pm 0.20^{\mathrm{b}}$ & $8.64 \pm 0.03^{\mathrm{a}, \mathrm{b}}$ \\
\hline
\end{tabular}

\footnotetext{
a $, \mathrm{b}, \mathrm{c},{ }^{\mathrm{d}}$ : The different letters in the table represent significant differences between treatments at $p<0.05$.
} 


\subsection{Effect of Nano-Hydroxyapatite on $\mathrm{Pb}$ Accumulation in Ryegrass}

The $\mathrm{Pb}$ content in shoots and roots are shown in Figure 2. The results showed that the metal content in shoots and roots was altered by the addition of $\mathrm{Pb}$ to the soil, as well as the addition of NHAP. Increasing concentrations of $\mathrm{Pb}$ in soil led to an increase of $\mathrm{Pb}$ content in roots and shoots. Compared to the control group, the addition of NHAP led to an approximately $2.86-21.1 \%$ decrease in $\mathrm{Pb}$ concentrations in the roots, and a $13.19-20.3 \%$ decrease in the shoots. There was a significant decrease in shoots with NHAP treatments compared to the control group, while the decrease caused by NHAP was not significant in roots, except at the highest concentration of $\mathrm{Pb}$ contamination. Plant-available $\mathrm{Pb}$ was highly correlated with water-soluble $\mathrm{Pb}(r=0.812$ for shoots, $p<0.05$; $r=0.870$ for roots; $p<0.01$ ). Thus, the application of NHAP decreased the Pb concentration of roots and shoots, because NHAP converted the bioavailable fractions of lead into bio-unavailable fractions.
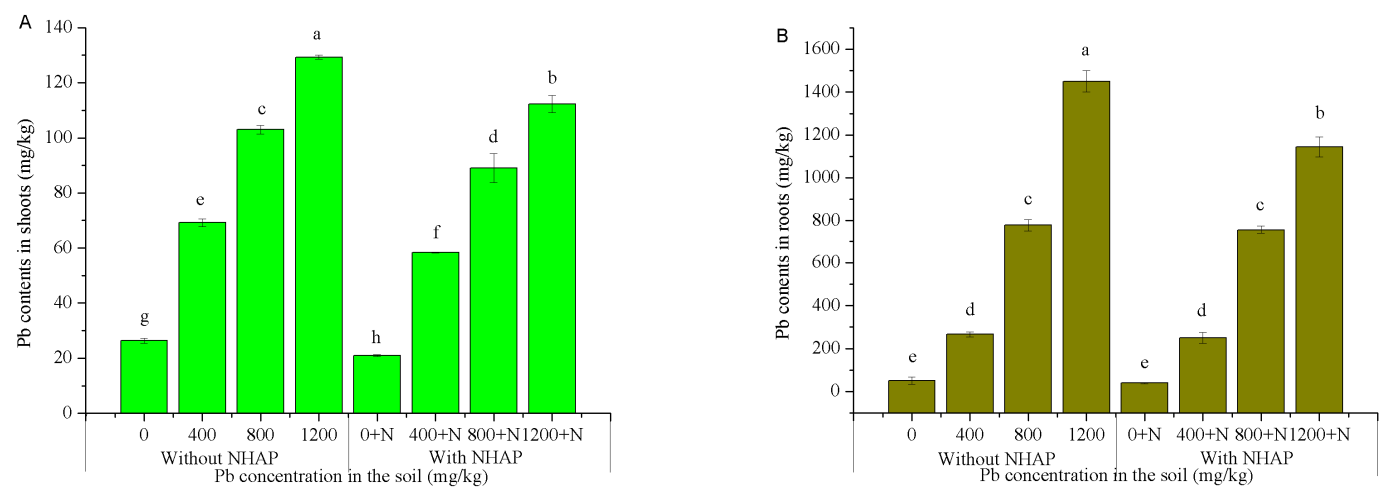

Figure 2. Effects of NHAP on Pb contents in shoots $(\mathbf{A})$ and roots $(\mathbf{B})$. $\mathrm{a}-\mathrm{h}$ : The different letters in the figure represent significant differences between treatments at $p<0.05$.

\subsection{Plant Growth and Biomass}

In this study, ryegrass grew rapidly and healthily, with no visual symptoms of necrosis or whitish-brown chlorosis during plant growth. After the plants were harvested, the height of ryegrass and the fresh weight were measured, and the results are shown in Figure 3. The average heights of the ryegrass shoots in the control group were $16.4 \mathrm{~cm}, 23.8 \mathrm{~cm}$, and $29.2 \mathrm{~cm}$, and the heights of those with added NHAP were $16.6 \mathrm{~cm}, 24.4 \mathrm{~cm}$, and $29.8 \mathrm{~cm}$, respectively. The addition of $\mathrm{Pb}$ did not cause obvious toxicity to the growth of ryegrass; only a slight inhibition. The total fresh weight of ryegrass with NHAP showed a significant increasing trend compared with the control group, and there was a higher increase in root weight compared to shoot weight. The fresh weight of shoot increased by an average of $12.35 \%$, while that of the root was $32.76 \%$. Ryegrass has very large and dense fibrous roots which spread to the entire soil core in the pots during the experimental period. NHAP reduced the mobility and bioavailability of $\mathrm{Pb}$, and alleviated the high toxicity of $\mathrm{Pb}$ to ryegrass. The $\mathrm{P}$ content in the soil was elevated after the addition of NHAP, which could promote plant growth and increase biomass. Thus, NHAP did not hinder the growth of ryegrass, but had a positive role in promoting its growth. 

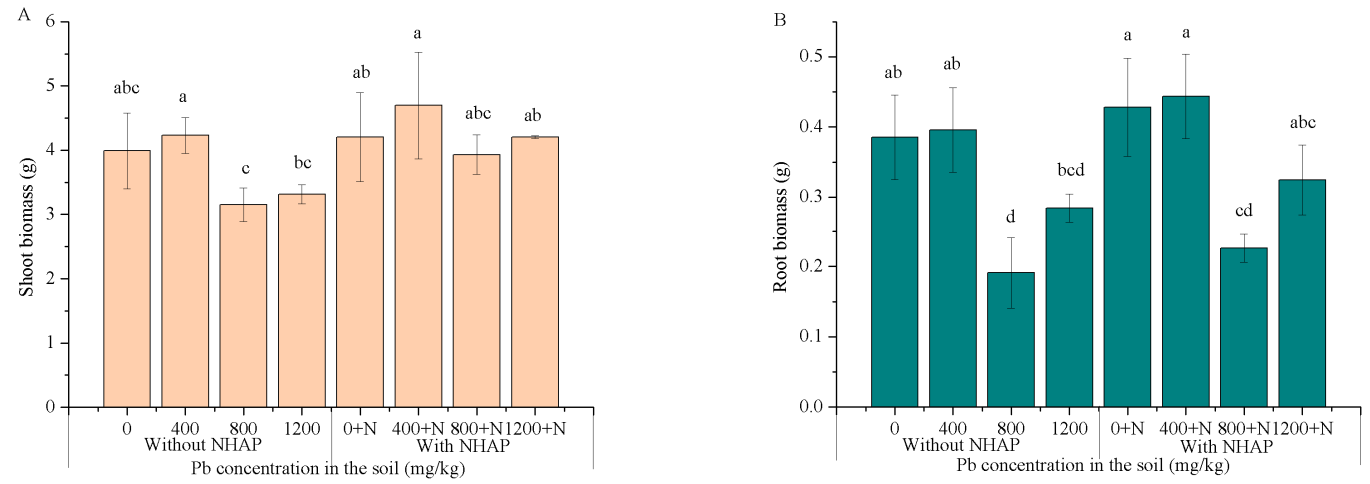

Figure 3. Effect of NHAP in different treatments on ryegrass shoot (A) and root (B) biomass. a, b, c, d: The different letters in the table represent significant differences between treatments at $p<0.05$.

\subsection{Organic Acid Response to Nano-Hydroxyapatitein the Ryegrass Rhizosphere}

Organic acids are widely present in plants and in the rhizosphere environment [30]. Under environmental stresses, such as heavy metals, organic acids secreted by plants were found to be significantly increased [31]. In this study, the low molecular weight organic acids in rhizosphere soil were measured after harvest at day 30 . Tartaric acid was detected in perennial ryegrass rhizosphere soil, while other organic acids were below the limits of detection. As shown in Figure 4, tartaric acid content increased significantly along with the increase in $\mathrm{Pb}$ content in the soil. The tartaric acid contents were significantly positively correlated to the soil $\mathrm{Pb}$ contents in all treatments. This showed that secretion of tartaric acid by ryegrass was sensitive to $\mathrm{Pb}$ stress. The application of NHAP caused an increase in tartaric acid content by an average of $98.82 \%$ compared with the treatments without the addition of NHAP. The probable cause for this was that NHAP administration promoted the growth of ryegrass. It has been reported that plant root secretion of organic acids can improve the mobility and bioavailability of heavy metals in soil [32,33]. The increase of tartaric acid content also increased the likelihood that ryegrass absorbed $\mathrm{Pb}$ from rhizosphere soil. The objective of NHAP application was to lower the bioavailability of $\mathrm{Pb}$, which seemed to be inconsistent with the role of tartaric acid. It has been reported that low molecular weight organic acids, including acetic acid, malic acid, citric acid, and oxalic acid, promoted the adsorption of $\mathrm{Pb}^{2+}$ on the surface of NHAP [34]. Therefore, the increase in tartaric acid could be considered as a beneficial aspect of NHAP for plant growth and reducing the bioavailabiliy of $\mathrm{Pb}$. Tartaric acid had no inhibition effect on the remediation results of NHAP.

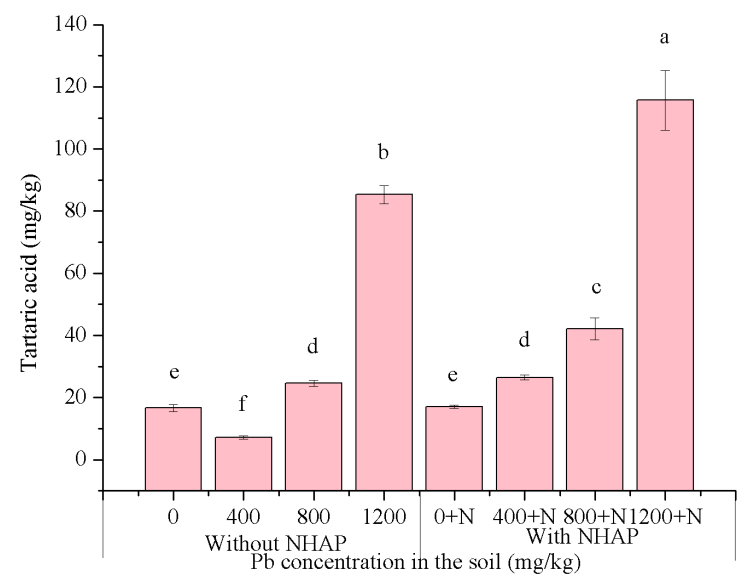

Figure 4. Tartaric acid contents in ryegrass rhizosphere soil under different treatments. a-f: The different letters in the table represent significant differences between treatments at $p<0.05$. 


\section{Conclusions}

This study illustrated that NHAP could significantly reduce the mobility and bioavailability of $\mathrm{Pb}$. The addition of NHAP effectively reduced the exchangeable and reducible fractions of $\mathrm{Pb}$ in soil, and transformed them into oxidizable and residual $\mathrm{Pb}$, limiting its mobility and bioavailability. NHAP could play a very large role in controlling and mitigating the dangers of $\mathrm{Pb}$ pollution for organisms and the environment. The $\mathrm{Pb}$ contents of shoots and roots decreased and soil $\mathrm{pH}$ did not change significantly with the addition of NHAP; moreover, NHAP promoted the growth of ryegrass and the secretion of tartaric acid. This also indicated that the application of NHAP was beneficial to the growth of plants, and did not have negative impacts on the environment. The results in this study showed that NHAP could immobilize $\mathrm{Pb}$ in contaminated soil effectively, and can benefit the growth of ryegrass.

Acknowledgments: This study was supported by the Natural Science Foundation of Hebei Province (B2014201175) and the Hebei Provincial Project of International Cooperation in Science and Technology (14394204D).

Author Contributions: Shu-xuan Liang and Wei Liu conceived and designed the experiments; Ling Ding and Qingqing Zuo performed the experiments; Ling Ding analyzed the data; Ling Ding, Shu-xuan Liang and Jianbing Li wrote the paper.

Conflicts of Interest: The authors declare no conflict of interest.

\section{References}

1. Shrivastava, R.; Upreti, R.K.; Chaturvedi, U.C. Various cells of the immune system and intestine differ in their capacity to reduce hexavalent chromium. FEMS Immunol. Med. Microbiol. 2003, 38, 65-70. [CrossRef]

2. Miller, G.; Begonia, G.; Begonia, M.; Ntoni, J. Bioavailability and uptake of lead by coffeeweed (Sesbania exaltata Raf.). Int. J. Environ. Res. Public Health 2008, 5, 436-440. [CrossRef] [PubMed]

3. Boisson, J.; Ruttens, A.; Mench, M.; Vangronsveld, J. Evaluation of hydroxyapatite as a metal immobilizing soil additive for the remediation of polluted soils. Part 1. Influence of hydroxyapatite on metal exchangeability in soil, plant growth and plant metal accumulation. Environ. Pollut. 1999, 104, 225-233. [CrossRef]

4. Flora, G.; Gupta, D.; Tiwari, A.A. Toxicity of lead: A review with recent updates. Interdiscip. Toxicol. 2012, 5, 47-58. [CrossRef] [PubMed]

5. Govarthanan, M. Lead biotransformation potential of allochthonous Bacillus sp. SKK11 with sesame oil cake extract in mine soil. RSC Adv. 2015, 5, 54564-54570.

6. Chinese Environmental Protection Administration. Environmental Quality Standards for Soils; GB15618-1995; Chinese Environmental Protection Administration: Beijing, China.

7. Guo, G.; Zhou, Q.; Ma, L.Q. Availability and assessment of fixing additives for the in situ remediation of heavy metal contaminated soils: A review. Environ. Monit. Assess. 2006, 116, 513-528. [CrossRef] [PubMed]

8. Wani, S.H.; Sanghera, G.S.; Athokpam, H. Phytoremediation: Curing soil problems with crops. Afr. J. Agric. Res. 2012, 7, 3991-4002.

9. Miretzky, P.; Fernandez-Cirelli, A. Phosphates for Pb immobilization in soils: A review. Environ. Chem. Lett. 2008, 6, 121-133. [CrossRef]

10. Chrysochoou, M.; Dermatas, D.; Grubb, D.G. Phosphate application to firing range soils for $\mathrm{Pb}$ immobilization: The unclear role of phosphate. J. Hazard. Mater. 2007, 144, 1-14. [CrossRef] [PubMed]

11. Zhang, Z.; Li, M.; Chen, W.; Zhu, S.Z.; Liu, N.N.; Zhu, L.Y. Immobilization of lead and cadmium from aqueous solution and contaminated sediment using nano-hydroxyapatite. Environ. Pollut. 2009, 158, 514-519. [CrossRef] [PubMed]

12. Sarma, H. Metal hyperaccumulation in plants: A review focusing on phytoremediation technology. Environ. Sci. Technol. 2011, 4, 118-138. [CrossRef]

13. Gu, C.; Bai, Y.; Tao, T. Effect of sewage sludge amendment on heavy metal uptake and yield of ryegrass seedling in a mudflat soil. J. Environ. Qual. 2013, 42, 421-428. [CrossRef] [PubMed]

14. Jin, Y.; Liu, W.; Li, X.L.; Shen, S.G.; Liang, S.X.; Liu, C.Q.; Shan, L.Y. Nano-hydroxyapatite immobilized lead and enhanced plant growth of ryegrass in a contaminated soil. Ecol. Eng. 2016, 95, 25-29. [CrossRef] 
15. Fang, X.; You, M.P.; Barbetti, M.J. Reduced severity and impact of Fusarium wilt on strawberry by manipulation of soil $\mathrm{pH}$, soil organic amendments and crop rotation. Eur. J. Plant Pathol. 2012, 134, 619-629. [CrossRef]

16. Bradstreet, R.B. The Kjeldahl Method for Organic Nitrogen. Anal. Chem. 1954, 26, 169-234. [CrossRef]

17. Chacón, N.; Herrera, I.; Flores, S.; González, J.A.; Nassar, J.M. Chemical, physical, and biochemical soil properties and plant roots as affected by native and exotic plants in neotropical arid zones. Biol. Fertil. Soils 2009, 45, 321-328. [CrossRef]

18. Gillman, G.P.; Bruce, R.C.; Davey, B.G. A comparison of methods used for determination of cation exchange capacity. Commun. Soil Sci. Plant Anal. 1983, 14, 1005-1014. [CrossRef]

19. Yang, X.; Liu, J.; Mcgrouther, K. Effect of biochar on the extractability of heavy metals $(\mathrm{Cd}, \mathrm{Cu}, \mathrm{Pb}$, and $\mathrm{Zn})$ and enzyme activity in soil. Environ. Sci. Pollut. Res. 2016, 23, 974-984. [CrossRef] [PubMed]

20. Freitas, E.V.; Nascimento, C.W.; Silva, W.M. Citric acid-assisted phytoextraction of lead in the field: The use of soil amendments. Water Air Soil Pollut. 2014, 225, 1-9. [CrossRef]

21. Tokalığlu, Ş.; Yılmaz, V.; Kartal, Ş. An assessment on metal sources by multivariate analysis and speciation of metals in soil samples using the BCR sequential extraction procedure. Clean-Soil Air Water 2010, 38, 713-718. [CrossRef]

22. Tessier, A.; Campbell, P.G.C.; Bisson, M. Sequential extraction procedure for the speciation of particulate trace metals. Anal. Chem. 1979, 51, 844-851. [CrossRef]

23. Ryan, J.A.; Zhang, P.; Hesterberg, D. Formation of Chloropyromorphite in a Lead-Contaminated Soil Amended with Hydroxyapatite. Environ. Sci. Technol. 2001, 35, 3798-3803. [CrossRef] [PubMed]

24. Kong, I.C.; Bitton, G. Correlation between heavy metal toxicity and metal fractions of contaminated soils in Korea. Bull. Environ. Contam. Toxicol. 2003, 70, 557-565. [CrossRef] [PubMed]

25. Ahmad, M.; Hashimoto, Y.; Moon, D.H.; Lee, S.S.; Ok, Y.S. Immobilization of lead in a Korean military shooting range soil using eggshell waste: An integrated mechanistic approach. J. Hazard. Mater. 2012, 4, 392-401. [CrossRef] [PubMed]

26. Yang, Z.; Fang, Z.; Zheng, L. Remediation of lead contaminated soil by biochar-supported nano-hydroxyapatite. Ecotoxicol. Environ. Saf. 2016, 132, 224-230. [CrossRef] [PubMed]

27. Li, Z.; Zhou, M.; Lin, W. The research of nanoparticle and microparticle hydroxyapatite amendment in multiple heavy metals contaminated soil remediation. J. Nanomater. 2014, 17, 1-8. [CrossRef]

28. Lusvardi, G.; Malavasi, G.; Menabue, L.; Saladini, M. Removal of cadmium ion by means of synthetic hydroxyapatite. Waste Manag. 2002, 22, 853-857. [CrossRef]

29. Silber, A.; Yones, L.B.; Dori, I. Rhizosphere $\mathrm{pH}$ as a result of nitrogen levels and $\mathrm{NH}_{4} / \mathrm{NO}_{3}$ ratio and its effect on zinc availability and on growth of rice flower (Ozothamnus diosmifolius). Plant Soil 2004, 262, 205-213. [CrossRef]

30. López-Bucio, J.; Nieto-Jacobo, M.F.; Ramírez-Rodríguez, V.; Herrera-Estrella, L. Organic acid metabolism in plants: From adaptive physiology to transgenic varieties for cultivation in extreme soils. Plant Sci. 2000, 160, 1-13. [CrossRef]

31. Ding, Y.Z.; Song, Z.G.; Feng, R.W.; Guo, J.K. Interaction of organic acids and pH on multi-heavy metal extraction from alkaline and acid mine soils. Int. J. Environ. Sci. Technol. 2014, 11, 1-10. [CrossRef]

32. Debela, F.; Arocena, J.M.; Thring, R.W.; Whitcombe, T. Organic acid-induced release of lead from pyromorphite and its relevance to reclamation of $\mathrm{Pb}$-contaminated soils. Chemosphere 2010, 80, 450-456. [CrossRef] [PubMed]

33. Park, J.H.; Lamb, D.; Paneerselvam, P.; Choppala, G.; Bolan, N.; Chung, J.W. Role of organic amendments on enhanced bioremediation of heavy metal(loid) contaminated soils. J. Hazard. Mater. 2011, 85, 549-574. [CrossRef] [PubMed]

34. Wang, S.T.; Liu, H.L.; Liu, W.; Zuo, Q.Q. Effect of low-molecular-weight organic acids on nano-hydroxyapatite adsorption of cadmium and lead. J. Biomater. Tissue Eng. 2016, 6, 433-439. [CrossRef]

(C) 2017 by the authors. Licensee MDPI, Basel, Switzerland. This article is an open access article distributed under the terms and conditions of the Creative Commons Attribution (CC BY) license (http:/ / creativecommons.org/licenses/by/4.0/). 